Jurnal Kesehatan Karya Husada, Vol 9 No 1 Tahun 2021

PISSN 2337649X/EISSN 2655-8874

Dhiya Urrahman, Sumarti Endah PMMM, Abdul Aziz"Injury Perawatan pada Penggunaan Alat Pelindung Diri (APD) dalam Pelayanan Covid-19" (hal 91-103)

Received

Revisied

Acceptep

17 Desember 2020

27 Februari 2021

16 Juni 2021

\title{
INJURY PERAWAT PADA PENGGUNAAN ALAT PELINDUNG DIRI (APD) DALAM PELAYANAN COVID-19
}

\author{
Dhiya Urrahman ${ }^{1)}$ Sumarti Endah PMM $^{2)}$ Abdul Aziz ${ }^{3)}$ \\ ${ }^{1}$ Politeknik Kesehatan Karya Husada Yogyakarta \\ Email : dhiyar.du@gmail.com \\ ${ }^{2}$ Politeknik Kesehatan Karya Husada Yogyakarta \\ Email : sumartiendah@gmail.com \\ ${ }^{3}$ Politeknik Kesehatan Karya Husada Yogyakarta \\ Email : abdulaziz0165@gmail.com
}

\begin{abstract}
ABSTRAK
Latar belakang: Alat Pelindung Diri (APD) menjadi salah satu keharusan yang harus digunakan perawat dalam melayani pasien selama masa pandemic covid-19. Namun sayangnya APD yang digunakan dalam waktu jangka panjang menimbulkan cedera. Hal ini dapat mengakibatkan penurunan kinerja bahkan mengancam keselamatan perawatan.Tujuan: Menganalisis kejadian injury perawat pada penggunaan alat pelindung diri (APD) dalam pelayanan covid-19. Metode: penelitian ini menggunakan rancangan penelitian cross sectional. Sampel sebanyak 211 perawat diambil dengan tehnik snowball sampling. Analisa data menggunakan distribusi frekuensi, analisa bivariate menggunakan chi square dan analisa multivariat menggunakan regresi logistic. Hasil: Sebagian besar perawat dalam pemakaian APD selama pelayanan Covid-19 mengalami dengan jumlah 130 orang $(61,6 \%)$ dengan cedera tertinggi adalah lecet pada hidung yaitu 112 orang (86\%). Selanjutnya, terdapat hubungan yang bermakna antara usia dengan injury pada penggunaan APD jangka panjang $(\mathrm{p}=0,000)$ dan terdapat hubungan yang bermakna antara tempat kerja dengan injury pada penggunaan APD jangka panjang $(\mathrm{p}=0,000)$. Variabel usia menjadi prediktor kejadian injury perawat dalam pemakaian APD jangka panjang dengan nilai $\mathrm{p}=0,000$ dan $\mathrm{Wald}=29,029$. Kesimpulan: Terdapat kejadian injury perawat dalam pengguanaan Alat pelindung Diri (APD) jangka panjang dalam pelayanan Covid-19 dengan cedera tertinggi yaitu lecet hidung
\end{abstract}

Kata kunci: Injury AND Alat Pelindung Diri (APD) AND pelayanan Covid-19.

\section{NURSE INJURY ON THE USE OF PERSONAL PROTECTIVE EQUIPMENT (PPE) in COVID-19 SERVICES}


Background: Personal protective equipment (PPE) is a must for nurses to serve patients during the Covid-19 pandemic. But unfortunately PPE that is used in the long term causes injury. This can result in decreased performance and even threaten the safety of maintenance. Objective: To analyze the incidence of nurse injury in the use of personal protective equipment (PPE) in co-19 services.Methods: This study used a cross sectional study design. A sample of 211 nurses was taken using the snowball sampling technique. Data analysis using frequency distribution, bivariate analysis using chi square and multivariate analysis using logistic regression. Results: The majority of nurses in the use of PPE during Covid-19 service experienced a total of 130 people $(61.6 \%)$ with the highest injury being blisters on the nose of 112 people $(86 \%)$. Furthermore, there is a significant relationship between age and injury in long-term PPE use $(\mathrm{p}=0,000)$ and there is a significant relationship between workplace and injury in long-term PPE use $(p=0,000)$. Age variable is a predictor of the incidence of injury to nurses in the long-term use of PPE with $p=0,000$ and Wald $=29,029$.Conclusion: There was a nurse injury incident in the use of long-term personal protective equipment (PPE) in the service of Covid-19 with the highest injury, namely nasal blisters

\section{Keywords: Injury AND Personal Protective Equipment AND Covid-19 services}

\section{PENDAHULUAN}

COVID-19 merebak dan menyebar dengan cepat dari Wuhan, Tiongkok lebih dari 80.000 orang terinfeksi dan lebih dari 3.000 pasien tewas oleh penyakit tersebut (Kraemer et al., 2020). Komisi Kesehatan Nasional Republik Rakyat China mengumumkan bahwa keadaan darurat kesehatan masyarakat terbesar dan terus merevisi pedoman diagnosis dan pengobatan COVID-19, bertujuan untuk mengendalikan epidemi dan mengurangi angka kematian (Shi et al., 2020). Studi awal menunjukkan bahwa yang dikonfirmasi kasus dan pembawa virus dapat menjadi sumber yang terinfeksi oleh orang ke orang, dalam menghadapi tantangan besar ini, lebih dari 40.000 staf medis atau keperawatan secara sukarela membantu Wuhan, dan puluhan ribu staf medis lainnya bergabung untuk memerangi COVID-19 di seluruh China (Dargaville, Spann and Celina, 2020).

Mereka bekerja setiap hari selama 812 jam dengan mengenakan alat pelindung diri (APD), termasuk masker pelindung, kacamata, pelindung wajah, dan pakaian pelindung.5,6 Sayangnya, 80\% dari mereka melaporkan bahwa cedera kulit yang berbeda merusak kesehatan mereka dan meningkatkan risiko infeksi (Jiang, Liu and Zhu, 2020). Menurut pedoman pemerintah, tenaga medis yang menangani kasus covid-19 yang mencurigakan di unit 
gawat darurat dan klinik skrining dianggap berisiko sedang, dan harus memakai masker bedah dengan kacamata atau masker pelindung wajah dan gaun pelindung (disebut sebagai APD kelas 2) bahwa staf medis yang merawat pasien COVID-19 di departemen infeksi, unit perawatan intensif (ICU), dan bangsal isolasi dianggap berisiko tinggi, dan harus memakai respirator N95/KN95 dengan kacamata atau masker pelindung wajah, pakaian pelindung, sarung tangan lateks, dan sepatu (dikenal sebagai grade 3PPE) (Perencevich et al., 2020).

Kami berhipotesis bahwa peningkatan durasi penggunaan APD mempengaruhi perkembangan sakit kepala terkait PPE serta menyebabkan injury pada tenaga kesehatan yang sudah ada sebelumnya. Kami mengevaluasi prevalensi dan karakteristik terjadinya injury kepada perawat terkait dengan lama paparan APD (khususnya masker wajah N95 dan / atau kacamata pelindung) di antara petugas layanan kesehatan di institusi kami. Selain itu, kami mengevaluasi dampak penggunaan APD pada gangguan kulit wajah, tangan maupun kaki yang sudah ada sebelumnya, yang diidentifikasi faktor risiko pengembangan injury terkait APD dan mengevaluasi dampak keseluruhan dari kepala hingga kaki selama COVID-19 terhadap kinerja petugas layanan kesehatan dirumah rujukan COVID-19 (Ong et al., 2020b).

\section{METODE PENELITIAN}

\section{Metode Desain Rancangan}

Penelitian ini menggunakan penelitian cross sectional (potong silang), yaitu sebab dan akibat yang terjadi pada objek penelitian diukur atau dikumpulkan secara simultan dan dalam waktu yang bersamaan (Notoatmodjo, 2015).

\section{Sampel Penelitian}

Sampel sebanyak 211 responden yang berprofesi perawat yang diambil dengan tehnik snowball sampling. Snowball sampling adalah teknik pengambilan sampel sumber data yang pada awalnya jumlahnya sedikit tersebut belum mampu memberikan data yang lengkap, maka harus mencari orang lain yang dapat digunakan sebagai sumber data (Sugiyono, 2014).

\section{Metode Pengumpulan Data}

Penelitian ini dimulai pada tanggal 15 April sampai dengan 10 Mei 2020. 
Metode pengumpulan data menggunakan data primer yang diperoleh dari pengisian kuesioner secara online memalui google form.

\section{Analisis Data}

Penelitian ini menggunakan analisa data univariat dengan menggunakan tabel distribusi frekuensi untuk mempelajari karakteristik dasar dan gambaran kejadian injury perawat pada penggunaan APD. Uji analisa bivariat menggunakan uji Chi square untuk membandingkan data demografi dengan kejadian injury perawat pada penggunaan APD dan analisa multivariat menggunakan uji regresi logistik dengan metode enter untuk mengetahui variabel prediktor paling dominan yang berhubungan dengan kejadian injury perawat pada penggunaan APD.

\section{HASIL PENELITIAN}

Pada penelitian ini ada beberapa hasil yang akan dijabarkan, yaitu terkait demografi dari responden, injury pada penggunaan alat pelindung diri (APD) jangka panjang dalam pelayanan covid-19, serta hubungan demografi responden dengan injury akibat pemakaian APD jangka panjang.

\section{Demografi Responden}

Tabel 1. Demografi Responden $(\mathrm{n}=211)$

\begin{tabular}{|c|c|c|}
\hline Variabel & Frekuensi & Persentase (\%) \\
\hline \multicolumn{3}{|l|}{ Jenis Kelamin } \\
\hline Wanita & 122 & 57,8 \\
\hline Pria & 89 & 42,2 \\
\hline Jumlah & 211 & 100 \\
\hline \multicolumn{3}{|l|}{ Usia } \\
\hline $21-40$ & 145 & 68.7 \\
\hline$>40$ & 66 & 31.3 \\
\hline Jumlah & 211 & 100 \\
\hline \multicolumn{3}{|l|}{ Pendidikan } \\
\hline Diploma & 82 & 38.9 \\
\hline Sarjana & 129 & 61.1 \\
\hline Jumlah & 211 & 100 \\
\hline \multicolumn{3}{|l|}{ Tempat Kerja } \\
\hline $\begin{array}{l}\text { Rujukan } \\
\text { Covid-19 }\end{array}$ & 77 & 36.5 \\
\hline Rujukan Covid-19 & 134 & 63.5 \\
\hline Jumlah & 211 & 100 \\
\hline
\end{tabular}

Karakteristik responden menurut tabel 1 sebagian besar berjenis kelamin wanita $122(57,8 \%)$, berusia antara $21-40$ tahun $145(68,7 \%)$, berpendidikan sarjana $129(61,1 \%)$, dan bekerja di rujukan covid$19134(63,5 \%)$.

\section{Injury pada Penggunaan Alat} Perlindungan Diri (APD) Jangka Panjang dalam Pelayanan Covid-19

Kejadian injuri pada perawat selama penggunaan APD dapat dilihat pada tebel 2 berikut: 
Jurnal Kesehatan Karya Husada, No 9 Vol 1 Tahun 2021

PISSN 2337649X/EISSN 2655-8874

Dhiya Urrahman, Sumarti Endah PMMM, Abdul Aziz"Injury Perawatan pada Penggunaan Alat Pelindung Diri (APD) dalam Pelayanan Covid-19" (hal 91-103)

Tabel 2. Injuri Pada Penggunaan APD

Jangka Panjang Perawat Dalam Pelayanan

Covid-19 (N=211).

\begin{tabular}{lcc}
\hline Kejadian injury & $\begin{array}{c}\text { Frekue } \\
\text { nsi }\end{array}$ & $\begin{array}{c}\text { Persentas } \\
\text { e (\%) }\end{array}$ \\
\cline { 2 - 2 } tidak ada & 81 & 38.4 \\
Ada & 130 & 61.6 \\
\hline Jumlah & $\mathbf{2 1 1}$ & $\mathbf{1 0 0}$ \\
\hline
\end{tabular}

Sebanyak 130 responden $(61,6 \%)$ mengalami injury pada pemakaian APD jangka panjang dan hanya 81 orang $(38,4 \%)$ yang tidak mengalami injury. Jenis cedera dan ketidaknyamanan pada responden akibat pemakaian APD yang terlalu lama dapat dilihat pada grafik 1 :

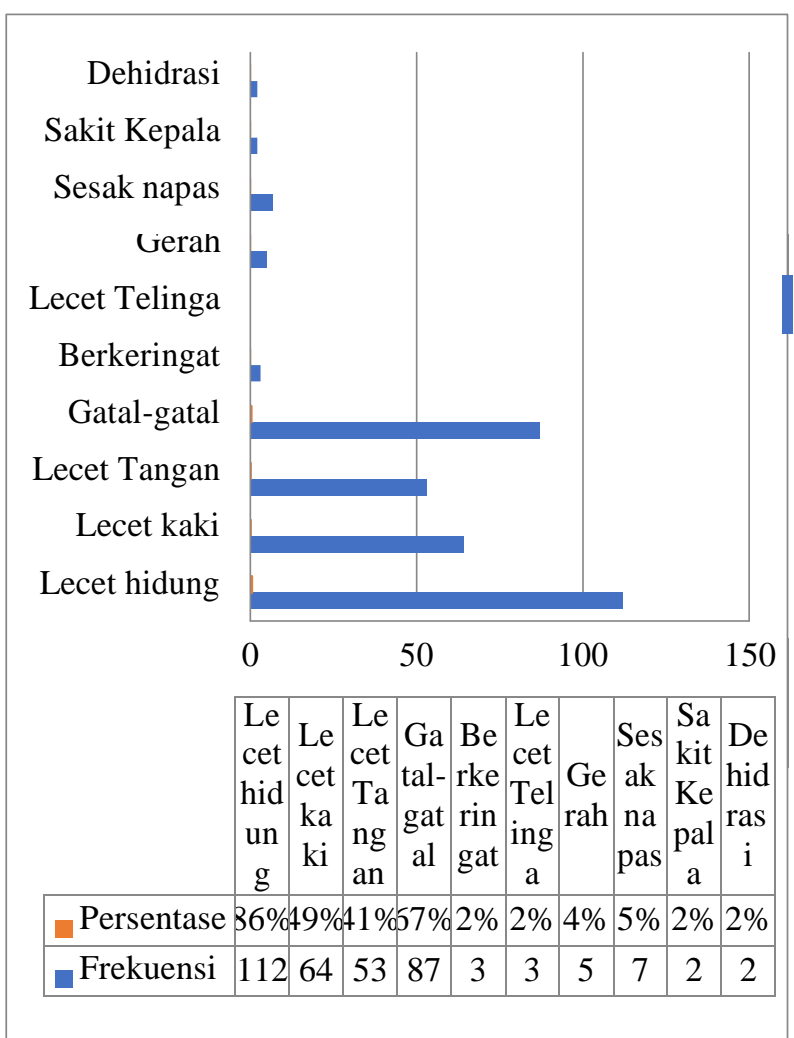

Grafik 1. Cedera Akibat Pemakaian APD

Lecet hidung merupakan cedera yang paling banyak dialami perawat selama pemakaian APD yaitu 112 orang (86\%). Kemudian sakit kepala dan dehidrasi paling sedikit dirasakan akibat penggunaan APD yang terlalu lama.

\section{Hubungan Demografi Responden Dengan Injury Akibat Pemakaian APD Jangka Panjang}

Tabel 3. Hubungan antara demografi responden dengan kejadian injury perawat pada penggunaan APD jangka panjang $(n=211)$

\begin{tabular}{|c|c|c|c|c|}
\hline \multirow{2}{*}{$\begin{array}{l}\text { Variabel } \\
\text { Demograf } \\
\text { i }\end{array}$} & \multicolumn{2}{|c|}{ Kejadian Injury } & \multirow{2}{*}{$\frac{\text { Total }}{\text { N }(\%)}$} & \multirow{2}{*}{$\begin{array}{c}\text { Nilai } \\
\text { p }\end{array}$} \\
\hline & $\begin{array}{c}\text { Tidak Ada } \\
\mathbf{N}(\%) \\
\end{array}$ & $\begin{array}{c}\text { Ada } \\
\mathbf{N}(\%) \\
\end{array}$ & & \\
\hline Jenis & & & & 0,8 \\
\hline Kelamin & & & & 11 \\
\hline Wanita & $46(21,8)$ & $76(36)$ & $122(57,8)$ & \\
\hline Pria & $35(16,6)$ & $54(25,6)$ & $89(42,2)$ & \\
\hline Jumlah & $81(38,4)$ & $130(61,6)$ & $211(100)$ & \\
\hline & $75(35,5)$ & $70(33,2)$ & $145(68,7)$ & $\begin{array}{c}0,0 \\
00\end{array}$ \\
\hline$>40$ & $6(2,8)$ & $60(28,4)$ & $66(31,3)$ & \\
\hline Jumlah & $81(38,4)$ & $130(61,6)$ & $211(100)$ & \\
\hline $\begin{array}{l}\text { Pendidika } \\
n\end{array}$ & & & & $\begin{array}{l}0,6 \\
59\end{array}$ \\
\hline Diploma & $33(15,6)$ & $49(23,2)$ & $82(38,9)$ & \\
\hline Sarjana & $48(22,7)$ & $81(38,4)$ & $129(61,1)$ & \\
\hline Jumlah & $81(38,4)$ & $130(61,6)$ & $211(100)$ & \\
\hline Tempat & & & & 0,00 \\
\hline Kerja & & & & 0 \\
\hline $\begin{array}{l}\text { Rujukan } \\
\text { Non }\end{array}$ & $14(6,6)$ & $63(29,9)$ & $77(36,5)$ & \\
\hline $\begin{array}{l}\text { Covid-19 } \\
\text { Rujukan } \\
\text { Covid-19 } \\
\end{array}$ & $67(31,8)$ & $67(31,8)$ & $134(63,5)$ & \\
\hline Jumlah & $81(38,4)$ & $130(61,6)$ & 211(100) & \\
\hline
\end{tabular}

Pada tabel 3, dapat dilihat bahwa responden yang berjenis kelamin wanita 
sebagian besar mengalami injury akibat pemakaian APD terlalu lama dengan jumlah 76 responden (36\%), sedangkan pada pria mayoritas 54 orang $(25,6 \%)$ juga mengalami injury. Responden yang berusia antara 21 sampai 40 tahun lebih banyak tidak mengalami injury yaitu 75 orang $(35,5 \%)$ sedangkan responden yang berusia $>40$ tahun paling banyak mengalami injury yaitu 60 orang $(28,4 \%)$. Pendidikan responden dengan lulusan diploma mayoritas mengalami injury 49 orang $(23,2 \%)$ sedangkan pendidikan sarjana jauh lebih banyak yang mengalami injury dengan jumlah 81 orang $(38,4 \%)$. Tempat kerja responden yang berstatus rujukan Non-Covid-19 juga terbanyak mengalami injury $63(29,9 \%)$, sedangkan responden yang bekerja di RS rujukan Covid-19 menunjukkan jumlah yang sama pada responden yang mengalami injury maupun yang masing - masing berjumlah 67 orang $(31,8 \%)$.

Hasil uji statistic menunjukkan bahwa tidak ada hubungan antara jenis kelamin dengan injuri pada penggunaan APD $\quad(p=0,811)$ dan tidak ada hubungan antara pendidikan dengan injury pada penggunaan APD $(p=0,659)$, namun ada hubungan yang bermakna antara usia dengan injury pada penggunaan APD $(\mathrm{p}=0,000)$, dan ada hubungan yang bermakna antar tempat kerja dengan injury pada penggunaan APD pada perawat dalam pelayanan Covid-19 $(\mathrm{p}=0,000)$.

Tabel 4. Hasil Analisis Multivariabel Regresi Logistik demografi responden yang berhubungan dengan injury pada penggunaan APD jangka panjang dalam pelayanan Covid$19(\mathrm{n}=211)$

\begin{tabular}{lccc}
\hline $\begin{array}{lcc}\text { Variabel } \\
\text { Demografi }\end{array}$ & Wald & & Nilai p \\
\cline { 1 - 1 } Usia & 29,029 & & 0,000 \\
Jenis kelamin & 0,496 & & 0,481 \\
Pendidikan & 0,073 & & 0,787 \\
Tempat Kerja & 22,148 & 0,000 \\
\hline
\end{tabular}

Hasil uji statistic regresi logistic sesuai dengan tabel 4 menunjukkan bahwa variable usia dan tempat kerja yang memiliki nilai $\mathrm{p}<0,05$ masing-masing dengan nilai $\mathrm{p}=0,000$ dengan nilai Wald untuk usia 29,029 dan tempat kerja yaitu 22,148. Hal ini dapat disimpulkan bahwa variabel yang menjadi prediktor utama terjadinya injury pada pada perawat dalam penggunaan APD jangka panjang selama pelayanan Covid-19 sesuai tabel 4 adalah usia karena memiliki nilai wald tertinggi.

\section{PEMBAHASAN}

\section{Demografi Responden}


Karakteristik responden menurut tabel 1 sebagian besar berjenis kelamin wanita $122(57,8 \%)$, berusia antara $21-$ 40 tahun $145(68,7 \%)$, berpendidikan sarjana $129(61,1 \%)$, dan bekerja di rujukan covid-19 $134(63,5 \%)$.

Hasil Penelitian Jiang et al (2020) menunjukkan bahwa prevalensi cedera kulit antara dokter dan perawaT adalah perempuan, APD kelas 3 dan kelas 2, waktu pemakaian harian 4 dan 4 jam, usia 25 dan 45 tahun dengan tingkat pendidikan sarjana. Analisis regresi logistik menunjukkan bahwa APD dengan waktu pemakaian sehari-hari, banyak berkeringat, dan jenis kelamin wanita meningkatkan risiko cedera kulit pada saat pemakian alat pelindung diri (APD).

Sebanyak 65 petugas kesehatan disurvei dengan kuesioner berjenis kelamin perempuan dengan rata-rata umur 24-45 tahun. Enam puluh satu $(93,8 \%)$ dari mereka dengan jenjang pendidikan sarjana keperawatan,bekerja dirumah sakit yang menjadi rujukan covid-19 (Hu et al., 2020).

Tanggapan yang valid diterima dari $744(27 \%)$ adalah perawat sebagai petugas kesehatan. Usia rata-rata adalah 41 (3449), 1254 (46\%) adalah perempuan.
Bekerja di ICU khusus COVID-19, di area lain yang digunakan kembali sebagai ICU COVID-19, beberapa karakteristik berbeda di antara mereka yang bekerja di ICU khusus atau yang digunakan ulang COVID-19 dibandingkan dengan ICU campuran atau lainnya (Tabah et al., 2020).

Tenaga kesehatan yang terlibat dalam pelayanan COVID-19 dalam penelitian ini, terdiri perawat berjenis kelamin wanita $(83,7 \%)$. rata-rata pengalaman profesional dan bekerja dirumah sakit rujukan COVID-19, dengan pendidikan sarjana keperawatan, rata-rata usia 23-45 tahun. Diantaranya, distribusi lama pengalaman profesi masing-masing $<8,5$ tahun (junior) dan $\geq 8,5$ tahun (senior) adalah 50 dan 79 (Xia, Lu and Lv, 2020).

Jiang, Song, Zhou, Liu, Chen, Bai, Wang and Jiang, (2020) Sebanyak 65 petugas kesehatan disurvei dengan kuesioner. Enam puluh satu (93,8\%) perawat yang bekerja dirumah sakit rujukan COVID-19. Diantaranya, terdapat 5 laki-laki $(8,2 \%)$ dan 56 perempuan (91,8\%), dengan jenjang pendidikan sarjana keperawatan. (Ong et al., 2020a) sebanyak 160 perawat yang bekerja di garis depan rumah sakit rurjukan COVID- 
19 diundang untuk berpartisipasi dalam penelitian ini, mayoritas responden penelitian adalah perempuan, berusia 2135 tahun, dan etnis Tionghoa, dengan pendidikan terakhir perawat sarjana keperawatan.

\section{Injury perawat pada penggunaan APD} jangka panjang dalam pelayanan

\section{Covid-19}

Lecet hidung merupakan cedera yang paling banyak dialami perawat selama pemakaian APD yaitu 112 orang $(86 \%)$. Kemudian sakit kepala dan dehidrasi paling sedikit dirasakan akibat penggunaan APD yang terlalu lama.

Menurut Hirschmann et al., 2020) Meningkatkan kesadaran akan masalah ini akan membantu menghindari penularan COVID-19 di tempat kerja ke tim bedah melalui aerosolisasi darah atau cairan tubuh lainnya dan karenanya APD yang memadai harus tersedia dan digunakan selama operasi ortopedi. Perawat juga mengalami luka pada hidung dan lecet pada tangan beserta kaki dikarenakan teralalu lama memakai alat pelindung diri (APD). Selain itu, upaya harus dilakukan untuk meningkatkan bukti terkini terkait hal ini. (Ong et al., 2020a) hasil penelitian menunjukkan dengan presentase terjadi luka pada hidung dan lecet kaki di antara petugas perawatan kesehatan yang berada di garis depan yang berisiko tinggi di institusi tersier selama wabah COVID-19 saat ini di Singapura. Besarnya kondisi ini signifikan secara klinis dan dapat memburuk jika wabah saat ini menyebar luas dan bertahan lebih lama, mempengaruhi kinerja pekerja perawatan kesehatan. Mungkin, strategi yang lebih baik diperlukan untuk merancang berbagai peralatan perlindungan diri (APD) dan mengurangi waktu pemakian agar tidak sampai menimbulkan luka pada saat menggunakan APD.

Regula et al (2020) agar profesional perawatan kesehatan dapat memberikan perawatan yang aman, mereka membutuhkan perlindungan dan pelatihan yang memadai dalam penggunaannya. Ini menimbulkan dilema saat menggunakan APD dikarenakan terlalu lama menggunakan APD dapat menimbulkan luka pada hidung. Staf perawatan kesehatan ingin merawat pasien mereka dan pemerintah perlu menerapkan sistem untuk pandemi di masa depan yang 
melindungi dan mempertahankan tenaga kerja perawat yang bekerja dirumah sakit rujukan COVID-19. (Schuklenk, 2020) kami harus berterima kasih kepada profesional perawatan kesehatan yang bersedia merawat pasien COVID-19, jika tidak ada APD standar profesional, tetapi kami tidak memiliki alasan untuk menerima begitu saja bahwa akan ada saat dibutuhkan. Tidak ada profesional perawatan kesehatan yang dapat mampu menerima tingkat risiko yang lebih tinggi ketika menggunakan APD menimbulkan lecet pada hidung dan lecet (tangan dan kaki) di akibatkan terlalau lama memakai APD pada saat jam kerja. Menyediakan peralatan yang diperlukan untuk melindungi diri mereka secara efisien (Tabah et al., 2020).

Abdi et al (2020) pandemi COVID19 adalah tantangan dinamis bagi sistem kesehatan untuk menyelamatkan staf layanan kesehatan dan sumber daya peralatan dengan keputusan tepat waktu. Petugas kesehatan berisiko lebih tinggi karena terlalu lama menggunakan APD disaat jam kerja yang mengakibatkan lecet pada hidung dan lecet pada kaki. COVID19 terutama pada fase awal epidemi ketika perlindungan kurang optimal pada penggunaan alat pelindung diri (APD).

3. Hubungan demografi responden dengan Injury perawat pada penggunaan APD jangka panjang dalam pelayanan Covid-19

Konservasi APD yang ada adalah penting, seperti yang direkomendasikan oleh CDC. Hasi penelitian menunjukkan penggunaan yang terlalu lama dapat mengakibatkan luka saat menggunakan alat pelindung diri. Usai dapat memperngaruhi praktik dalam menggunakan APD dengan jumlah besar, seperti tindakan pencegahan kontak untuk beberapa penyakit menular. Tempat kerja perawat pada rumah sakit rujukan COVID-19 berisiko tinggi saat menggunakan APD di jam kerja yang terlalu lama (Bauchner, Fontanarosa and MD, 2020). pasien yang ditemukan negative COVID-19, APD yang sesuai harus digunakan oleh semua staf perawat wanita atau laki-laki diruang operasi. Namun, resiko lecet saat penggunaan alat pelindung diri (APD) dengan jam kerja yang terlalu lama dapat mengakibatkan lecet pada daerah yang memakai APD. Penggunaan APD harus diperhatikan dan ditingkatkan mengingat risiko tinggi 
Jurnal Kesehatan Karya Husada, No 9 Vol 1 Tahun 2021

PISSN 2337649X/EISSN 2655-8874

Dhiya Urrahman, Sumarti Endah PMMM, Abdul Aziz"Injury Perawatan pada Penggunaan Alat Pelindung Diri (APD) dalam Pelayanan Covid-19" (hal 91-103)

dalam pengguanaan APD untuk menjamin perawat di tempat kerja selama prosedur endonasal (Bann and Gniady, 2020).

Nguyen et al (2020) pandemi COVID-19 telah mendatangkan malapetaka pada sistem perawatan kesehatan rumah sakit rujukan COVID-19 di seluruh dunia. Protokol klinis untuk SAH harus disesuaikan untuk melindungi perawat pada usia >tahun dengan pengendalian infeksi, staf perawat penyedia layanan yang memadai, APD dan percakapan sumber daya perawatan kritis sambil mengoptimalkan keselamatan perawat ketika menggunakan APD terlalu lama di jam shift saat melakukan perawatan pada pasien. Kami memberikan rekomendasi potensial untuk penyesuaian protokol klinis SAH di era COVID-19 yang baru ini. (Sobel et al., 2020) jika triaging jenis prosedur dilakukan hanya berdasarkan alokasi sumber daya jangka pendek, pertimbangan harus diberikan pada operasi yang menggunakan lebih sedikit APD. Dalam situasi dimana kekurangan APD dan penggunaan APD jangka panjang dapat menimbulkan lecet dan irigasi pada wajah tangan dan kaki, pertimbangan dapat diberikan kepada manajemen yang lebih pasti yang mungkin memerlukan biaya untuk stock PPE agar perawat dengan usia $>40$ yang lebih tinggi resiko injury pada perawat, Sementara kekurangan PPE terkait pandemi COVID19 saat ini sedang ditangani secara nasional dan internasional (Phua et al., 2020).

(Jain, 2020) memanfaatkan APD yang tepat adalah kunci untuk memberikan perawatan yang aman bagi perawat dan pasien pasien COVID-19. Untuk mengatasinya, CDC mengizinkan penggunaan, penggunaan kembali, dan pemrosesan ulang masker N95 secara diperpanjang. Ini sebagian karena pemanfaatan APD yang tidak memadai. Risiko infeksi meningkat pada perawat wanita maupun laki-laki dengan bertambahnya usia $>40$ tahun. dan adanya komorbiditas. Orang Afrika-Amerika dan Latin berada pada peningkatan risiko dikarenakan bekerja dirumah sakit rujukan COVID-19. (Bharatendu et al., 2020) Penelitian kami menunjukkan bahwa penggunaan respirator N95 saja atau dikombinasikan dengan PAPR menghasilkan perubahan signifikan dalam parameter hemodinamik otak dan iritasi pada wajah, hidung dan tangan-kaki. Namun, perubahan ini, yang mungkin 
Jurnal Kesehatan Karya Husada, No 9 Vol 1 Tahun 2021

PISSN 2337649X/EISSN 2655-8874

Dhiya Urrahman, Sumarti Endah PMMM, Abdul Aziz"Injury Perawatan pada Penggunaan Alat Pelindung Diri (APD) dalam Pelayanan Covid-19" (hal 91-103)

berkontribusi pada timbulnya sakit kepala pada perawat karena pemakaian masker N95 terlalu lama, faktor usia perawat sangat memperngaruhi penggunaan APD dapat menyebabkan injury dikarenakan terlalu jam kerja rumah sakit rujukan COVID-19 (Ryan and El Ayadi, 2020).

\section{KESIMPULAN}

Sebagian besar perawat dalam pemakaian APD selama pelayanan Covid19 mengalami dengan jumlah 130 orang $(61,6 \%)$ dengan cedera tertinggi adalah lecet pada hidung yaitu 112 orang (86\%). Selanjutnya, terdapat hubungan yang bermakna antara usia dengan injury pada penggunaan APD jangka panjang $(\mathrm{p}=0,000)$ dan terdapat hubungan yang bermakna antara tempat kerja dengan injury pada penggunaan APD jangka panjang $(\mathrm{p}=0,000)$. Variabel usia menjadi prediktor kejadian injury perawat dalam pemakaian APD jangka panjang dengan nilai $\mathrm{p}=0,000$ dan Wald $=29,029$. Hasil penelitian ini dapat menjadi masukan untuk berbagai pihak dalam penyediaan APD yang memadai dengan tetap memperhatikan bahan baku APD yang aman untuk meminimalisir terjadinya injury.

\section{DAFTAR PUSTAKA}

Abdi, R. et al. (2020) 'Surgical Practice in the Shadow of COVID-19 Outbreak.', The archives of bone and joint surgery, 8(Suppl1), pp. 256-261. doi: 10.22038/abjs.2020.47757.2348.

Bann, D. V and Gniady, J. P. (2020) 'Impact of coronavirus ( COVID-19 ) on otolaryngologic surgery: Brief commentary', (March), pp. 1227-1234. doi: 10.1002/hed.26162.

Bauchner, H., Fontanarosa, M. P. B. and MD, E. H. L. (2020) 'Conserving Supply of Personal Protective Equipment-A Call for Ideas', Neonatology, 115(2), pp. 116-126. doi: $10.1159 / 000492859$.

Bharatendu, C. et al. (2020) 'Powered Air Purifying Respirator (PAPR) restores the N95 face mask induced cerebral hemodynamic alterations among Healthcare Workers during COVID-19 Outbreak', Journal of the Neurological Sciences. Elsevier, 417(August), p. $117078 . \quad$ doi: 10.1016/j.jns.2020.117078.

Dargaville, T., Spann, K. and Celina, M. (2020) 'Opinion to address the personal protective equipment shortage in the global community during the COVID19 outbreak', Polymer Degradation and Stability. Elsevier Ltd, 176, p. 109162. doi:

10.1016/j.polymdegradstab.2020.10916 2.

Hirschmann, M. T. et al. (2020) 'COVID19 coronavirus: recommended personal protective equipment for the orthopaedic and trauma surgeon', Knee Surgery, Sports Traumatology, Arthroscopy. Springer Berlin Heidelberg, 28(6), pp. 1690-1698. doi: 10.1007/s00167-020-06022-4. 
Jurnal Kesehatan Karya Husada, No 9 Vol 1 Tahun 2021

PISSN 2337649X/EISSN 2655-8874

Dhiya Urrahman, Sumarti Endah PMMM, Abdul Aziz"Injury Perawatan pada Penggunaan Alat Pelindung Diri (APD) dalam Pelayanan Covid-19" (hal 91-103)

$\mathrm{Hu}$, K. et al. (2020) 'The adverse skin reactions of health care workers using personal protective equipment for COVID-19', Medicine, 99(24), p. e20603. doi: 10.1097/MD.0000000000020603.

Jain, U. (2020) 'Risk of COVID-19 due to Shortage of Personal Protective Equipment', Cureus, 12(6), pp. 6-13. doi: $10.7759 /$ cureus.8837.

Jiang, Q., Song, S., Zhou, J., Liu, Y., Chen, A., Bai, Y., Wang, J., Jiang, Z., et al. (2020) 'The Prevalence, Characteristics, and Prevention Status of Skin Injury Caused by Personal Protective Equipment Among Medical Staff in Fighting COVID-19: A Multicenter, Cross-Sectional Study', Advances in wound care, 9(7), pp. 357364. doi: 10.1089/wound.2020.1212.

Jiang, Q., Song, S., Zhou, J., Liu, Y., Chen, A., Bai, Y., Wang, J. and Jiang, Z. (2020) 'The Prevalence, Characteristics, and Prevention Status of Skin Injury Caused by Personal Protective Equipment Among Medical Staff in Fighting COVID-19: A Multicenter , Cross-Sectional Study', 9(7), pp. 357-364. doi: 10.1089/wound.2020.1212.

Jiang, Q., Liu, Y. and Zhu, D. (2020) 'The prevalence, characteristics, and related factors of pressure injury in medical staff wearing personal protective equipment against COVID-19 in China: A multicentre cross- sectional survey', (April), pp. 1-10. doi: 10.1111/iwj.13391.

Kraemer, M. U. G. et al. (2020) 'The effect of human mobility and control measures on the COVID-19 epidemic in China', Science, 368(6490), pp. 493497. doi: 10.1126/science.abb4218.

Nguyen, T. N. et al. (2020) 'Subarachnoid hemorrhage guidance in the era of the COVID-19 pandemic À An opinion to mitigate exposure and conserve personal protective equipment', Journal of Stroke and Cerebrovascular Diseases. Elsevier Inc., 29(9), p. $105010 . \quad$ doi: 10.1016/j.jstrokecerebrovasdis.2020.10 5010 .

Notoatmodjo, S. (2015) Metodologi Penelitian Kesehatan. Edisi Revisi. revisi. Jakarta: Rineka Cipta.

Ong, J. J. Y. et al. (2020a) 'Associated With Personal Protective Equipment A Cross-Sectional Study Among Frontline Healthcare Workers During COVID-19', Headache, 60(5), pp. 864877. doi: 10.1111/head.13811.

Ong, J. J. Y. et al. (2020b) 'Headaches Associated With Personal Protective Equipment - A Cross-Sectional Study Among Frontline Healthcare Workers During COVID-19', Headache, 60(5), pp. 864-877. doi: 10.1111/head.13811.

Perencevich, E. N. et al. (2020) 'Moving Personal Protective Equipment Into the Community Face Shields and Containment of COVID-19', 323(22), pp. 8-9. doi: 10.1093/annhyg/meq044.

Phua, J. et al. (2020) 'Intensive care management of coronavirus disease 2019 (COVID-19): challenges and recommendations', The Lancet Respiratory Medicine. Elsevier Ltd, 8(5), pp. 506-517. doi: 10.1016/S22132600(20)30161-2.

Regula-, W. et al. (2020) 'Personal protective equipment and Covid-19- a risk to healthcare staff ?', 58, pp. 500502. doi: 10.1016/j.bjoms.2020.04.015.

Ryan, N. E. and El Ayadi, A. M. (2020) 'A call for a gender-responsive, intersectional approach to address COVID-19', Global Public Health. 
Taylor \& Francis, 0(0), pp. 1-9. doi: 10.1080/17441692.2020.1791214.

Schuklenk, U. (2020) 'What healthcare professionals owe us : why their duty to treat during a pandemic is contingent on personal protective equipment ( PPE )', pp. 432-435. doi: 10.1136/medethics2020-106278.

Shi, Y. et al. (2020) 'Knowledge and attitudes of medical staff in Chinese psychiatric hospitals regarding COVID19', Brain, Behavior, \& Immunity Health. Elsevier Ltd, 4(March), p. 100064. doi: 10.1016/j.bbih.2020.100064.

Sobel, D. et al. (2020) 'Personal Protective Equipment for Common Urologic Procedures Before and During the United States COVID-19 Pandemic: A Single Institution Study', Urology. Elsevier Inc., 141, pp. 1-6. doi: 10.1016/j.urology.2020.04.083.

Sugiyono (2014) Statistika Untuk Penelitian. Bandung: CV Alfabeta.

Tabah, A. et al. (2020) 'Personal protective equipment and intensive care unit healthcare worker safety in the COVID-19 era (PPE-SAFE): An international survey', Journal of Critical Care. Elsevier Inc., 59, pp. 7075. doi: 10.1016/j.jcrc.2020.06.005.

Xia, W., Lu, J. L. and Lv, Z. H. (2020) 'Investigation of adverse reactions in healthcare personnel working in Level 3 barrier protection PPE to treat COVID-19', Postgraduate Medical Journal, pp. 1-4. doi: 10.1136/postgradmedj-2020-137854. 